\title{
Variation in Body Weight, Organ Weight and Haematological Parameters of Rats Fed with Diets Based on Treated African kudzu (Pueraria phaseoloides, roxb. Benth) Seeds
}

\section{*11IFEANACHO, MO; ABBEY, BW; AYALOGU, EO}

\author{
Biochemistry Department, University of Port Harcourt, Rivers State, Nigeria \\ *Corresponding author email: mifeanacho@yahoo.com
}

\begin{abstract}
Food insecurity is a major problem of the developing nations. There is therefore a need to assess the nutritional potentials of some lesser-known foods particularly grains with the view of adding them to the food base. In this paper, processed kudzu seeds (cooked and autoclaved for different periods(20,40,60 minutes))and raw kudzu seeds were made into flour and compounded into diets. The diets along with the negative and positive control diets were fed to eight groups of wistar rats for 28 days. The rats fed raw kudzu and negative control diet showed negative mean weight changes($6.50 \mathrm{~g}$ and $-10.0 \mathrm{~g}$ )while those fed with positive control and treated kudzu diet showed positive mean weight changes with Diets 2(cooked kudzu) and Diet 8(positive control) having the highest values(55.10g and $90.0 \mathrm{~g}$ ). These changes were significantly different $(\mathrm{P}<0.05)$.The absolute and relative organ (liver, heart, kidney, pancreas, spleen and lungs) weight changes of the experimental animals did not follow any particular trend. Haematological parameters measured in the animals included, haemoglobin packed cell volume, white blood cells, neutrophils, eosinophil, monocytes, lymphocytes and basophils. Except for the values of haemoglobin and packed cell volume that were higher in positive reference diet $(12.56 \mathrm{~g} / 100 \mathrm{ml}$ and $37.2 \%)$ which were not significantly different $(\mathrm{P}<0.05)$ from the cooked diet $(12.0 \mathrm{~g} / 100 \mathrm{ml}$ and $36.33 \%)$ but significantly different from others, the remaining haematological parameters did not follow any particular trend in all the groups. The result showed that the treated flour supported growth but had no definite effect on other parameters measured. The flour can therefore support growth in higher animals. CJASEM
\end{abstract}

https://dx.doi.org/10.4314/jasem.v21i6.2

Key Words: Kudzu, cooked, autolaved, weight, organ, haematological.

Malnutrition is a major problem of the developing countries caused by several factors but mostly food insecurity. Food insecurity per se is a result of lack of access to food by individuals and households. Several strategies have been developed and used to reduce the menace. The strategies included investigation into the possibilities of using some wild and lesser known crops as food for man and animal. Most investigated food crops were usually legumes. Legumes are consumed universally on account of their high nutritive value. They are important sources of complex carbohydrates, unsaturated fats, minerals and vitamins. (Rajeev Bhat and Karim (2009), Yusuf et al., ( 2007).They also contain some non-nutrient phytochemicals which are gaining recognition due to claims of their therapeutic effects on some diseases. Recently, legumes are widely consumed because of their therapeutic value in the treatment and prevention of various non-communicable diseases like coronary diseases, some types of cancers, diabetes etc. ( Rebello et al., (2014) and Stanner et al.,(2004)).However, legumes contain several antinutritional factors in the raw seeds that need to be reduced by processing so as to enhance the nutritional quality. Some processing methods including dry heat and wet heat treatment, soaking, dehulling, fermentation, sprouting etc. have been used in the past.(Siddhuraju et al., (2002), Siddhuraju and Becker (2003))These methods have been shown to reduce some of these antinutrients and to improve their overall nutritional quality.(Akande, et al.,( 2010), Maria et al., (2015)). Kudzu is a wild legume plant used in soil conservation, the leaf is used as forage for animals especially rabbits in some African counties while the seeds are used as feed for birds in some Asian countries ((Kaufman(1986)).In an earlier study Ifeanacho et al., (2007), observed that kudzu contained substantial amount of protein,some essential some essential minerals as well as some antinutrients.However these antinutrients were drastically reduced by some applied heat treatments (Ifeanacho et al., (2008). This paper presents the variations in body weight, organ weight as well as some haematological parameters in rats fed raw and heat-treated kudzu diets.

\section{MATERIALS AND METHODS}

Sample Collection: Kudzu seeds were obtained from International Institute for Tropical Agriculture, (IITA) Onne, Rivers State while maize (Zea mays) grains and red palm oil were purchased from the Mile 3 Market, Port Harcourt, Rivers State. Granulated pure cane sugar (sucrose) and nutrend were purchased from Sunrise Supermarket, University of Port Harcourt. Vitamins and mineral mixtures were bought at Raf - Veterinary Store, Rumuigbo Port Harcourt, Rivers State.

Sample Preparation/Treatment: One kilogram $(1 \mathrm{~kg})$ of the seeds was washed with clean water and boiled

* Corresponding author email: mifeanacho@yahoo.com 
at $100^{\circ} \mathrm{C}$ in a closed saucepan over a kerosene stove until it became tender in 53minutes. Caution was exercised during the cooking such that the cooking water dried up within the cooking period and so no water was drained off at the end of the cooking. The cooked seeds were dried at $100^{\circ} \mathrm{C}$, milled into fine powder, put in polythene bag and stored in the refrigerator until it was used for analysis. On the other hand, one kilogram $(1 \mathrm{~kg})$ of the kudzu seeds each was autoclaved at $121^{\circ} \mathrm{C},(15 \mathrm{psi})$ for 20 minutes, 40 minutes and 60 minutes respectively. They were later ground into fine powder $(710 \mathrm{~mm}$ sieve) using an electric mill. They were individually packed in different polythene bags and stored in the refrigerator at $4^{\circ} \mathrm{C}$. One kilogram $(1 \mathrm{~kg})$ of raw (unprocessed) seeds of the kudzu was also milled and stored in the refrigerator. They were in the refrigerator until used for analysis.

Seven (7) diets were formulated using corn starch, kudzu flour (raw and processed), sucrose, nonnutritive cellulose, palm oil and vitamin/mineral mixture. As shown in Table 1, $\operatorname{diet}(1)$ contained the raw kudzu, $\operatorname{diet}(2)$ cooked kudzu, $\operatorname{diet}(3) \mathrm{kudzu}$ autoclaved at $121^{\circ} \mathrm{C}(15 \mathrm{psi})$ for 20 minutes, $\operatorname{diet}(4)$ kudzu autoclave at $121^{\circ} \mathrm{C}(15 \mathrm{psi})$ for 40 minutes, $\operatorname{diet}(5)$ kudzu autoclave at $121^{\circ} \mathrm{C}$ (15psi) for 60 minutes. The sixth diet (6) was the basal diet (protein free diet) while diet seven (7) was made up of $100 \%$ cooked kudzu and diet eight (8) was the reference diet (nutrend). The diets were formulated to provide $16 \%$ protein.

A total of forty(40) weaning albino rats of the Wistar strain aged between 24-28 days, obtained from the Biochemistry Department, University of PortHarcourt were used the for the study. They were divided into eight (8) groups of five (5) rats each on the basis of their body weight. The rats were singly housed in perforated Perspex wire bottom cages with facilities for food, water and faecal collection. The rats were acclimatized for seven (7) days and fed with the experimental diet and water ad libitum for 28 days. The rats were weighed at intervasl during the experiment and at the end the final weight were taken and the change in body weight calculated. They were then sacrificed by cervical dislocation on the $28^{\text {th }}$ day. Their blood was collected into sample bottles with ethylene diamine tetra acetic acid (EDTA) as an anti-coagulant for haematological analysis.The animals were dissected; their liver, heart, kidney, spleen and pancreas were exercised, weighed and inspected for any pathological abnormalities.Haematological indices were determined using Medonic M16 Haematological Analyzer (Nelson Biochemical, Limited.,UK).

Statistical Analysis: The results were analyzed statistically by the use of one way analysis of variance (ANOVA) to determine the differences between the mean values at $\mathrm{P}<0.05$ level (Norusis, (1986)

\section{RESULTS AND DISCUSSION}

Table 1: Initial and Final Body Weight and Body Weight Change of Rats at the End of the Experimental Period (G)

\begin{tabular}{clll}
\hline & $\begin{array}{l}\text { Initial Body } \\
\text { Weight }\end{array}$ & $\begin{array}{l}\text { Final Body } \\
\text { Weight }\end{array}$ & $\begin{array}{l}\text { Weight } \\
\text { change }\end{array}$ \\
\hline Diet 1 & $75.25^{\mathrm{a}}$ & $68.75^{\mathrm{a}}$ & $-6.50^{\mathrm{a}}$ \\
& \pm 2.90 & \pm 2.40 & \pm 0.70 \\
Diet 2 & $75.10^{\mathrm{a}}$ & $130.20^{\mathrm{e}}$ & $55.10^{\mathrm{c}}$ \\
& \pm 2.50 & \pm 1.80 & \pm 1.31 \\
Diet 3 & $72.26^{\mathrm{a}}$ & $93.50^{\mathrm{b}}$ & $21.25^{\mathrm{b}}$ \\
& \pm 2.60 & \pm 2.40 & \pm 0.89 \\
Diet 4 & $75.30^{\mathrm{a}}$ & $125.40^{\mathrm{a}}$ & $50.10^{\mathrm{c}}$ \\
& \pm 2.70 & \pm 2.20 & \pm 1.01 \\
Diet 5 & $75.30^{\mathrm{a}}$ & $123.30^{\mathrm{d}}$ & $50.0^{\mathrm{c}}$ \\
& \pm 1.40 & \pm 2.50 & \pm 1.50 \\
Diet 6 & $73.40^{\mathrm{a}}$ & $63.40^{\mathrm{a}}$ & $-10.0^{\mathrm{a}}$ \\
& \pm 1.80 & \pm 1.40 & \pm 0.90 \\
Diet 7 & $74.25^{\mathrm{a}}$ & $122.35^{\mathrm{c}}$ & $48.10^{\mathrm{c}}$ \\
& \pm 2.75 & \pm 2.70 & \pm 1.08 \\
Diet 8 & $73.40^{\mathrm{a}}$ & $163.40^{\mathrm{e}}$ & $90.0^{\mathrm{d}}$ \\
& \pm 2.10 & \pm 2.20 & \pm 1.30 \\
\hline
\end{tabular}

Values are means \pm standard deviations of 5 animals.

Means with different superscript letters in the same row are significantly different at $5 \%$ level $(\mathrm{p}<0.05)$.

The initial and final body weight changes of rats at the end of the experimental period are presented in Table 1.Rats fed Diet 1 (raw kudzu) and Diet 6 (Basal diet) had negative weight change (-6.50 $\pm 12.34 \mathrm{~g}$ and $-10.0 \pm 12.25 \mathrm{~g})$ respectively while rats fed the remaining Diets 2, 3, 4, 5,7and 8 recorded increases in weight. Diet 8 (reference) had the highest weight increase $(90.0 \pm 13.69 \mathrm{~g})$ followed by Diet 2 (cooked kudzu) $(51.1 \pm 8.67 \mathrm{~g})$, then Diet 4 (40 minutes autoclaved) $(50.0 \pm 0.01 \mathrm{~g})$, Diet 5 (60 minutes autoclaved) $(50.0 \pm 25.0 \mathrm{~g})$ and Diet $7(100 \%$ cooked kudzu) $(48.1 \pm 17.8 \mathrm{~g})$ while Diet 3 (20 minutes) had the least weight increase (21.25 \pm $4.29 \mathrm{~g}$ ). The increase in weight by rats fed Diet 8 was significantly different $(\mathrm{p}<0.05)$ from the other diets while Diets 2, 4, 5 and 7 were not statistically different from each other. 
Variation in Body Weight, Organ Weight and Haematological Parameters

Table 2: Absolute organ weights of rats at the end of feeding study (28 days)

\begin{tabular}{lllllll}
\hline Diet group & Liver $(\mathrm{g})$ & Heart $(\mathrm{g})$ & Kidney $(\mathrm{g})$ & Pancreas $(\mathrm{g})$ & Spleen $(\mathrm{g})$ & Lungs $(\mathrm{g})$ \\
\hline & & & & & & \\
1 & $1.91^{\mathrm{a}}$ & $0.30^{\mathrm{ab}}$ & $0.63^{\mathrm{bc}}$ & $0.15^{\mathrm{a}}$ & $0.0 .19^{\mathrm{a}}$ & $0.40^{\mathrm{a}}$ \\
& \pm 0.37 & \pm 0.09 & \pm 0.13 & \pm 0.06 & \pm 0.10 & \pm 0.12 \\
& $4.11^{\mathrm{bc}}$ & $0.39^{\mathrm{bcd}}$ & $0.87^{\mathrm{de}}$ & $0.45^{\mathrm{abc}}$ & $0.32^{\mathrm{abc}}$ & $0.78^{\text {acd }}$ \\
3 & \pm 0.7 & \pm 0.02 & \pm 0.05 & \pm 0.07 & \pm 0.01 & \pm 0.06 \\
& $2.50^{\mathrm{a}}$ & $0.23^{\mathrm{a}}$ & $0.57^{\mathrm{ab}}$ & $0.45^{\mathrm{bcd}}$ & $0.25^{\mathrm{ab}}$ & $0.52^{\mathrm{b}}$ \\
4 & \pm 0.92 & \pm 0.07 & \pm 0.17 & \pm 0.09 & \pm 0.06 & \pm 0.02 \\
& $5.07^{\mathrm{c}}$ & $0.51^{\mathrm{cd}}$ & $0.81^{\text {cde }}$ & $0.58^{\mathrm{d}}$ & $0.45^{\text {cd }}$ & $0.92^{\mathrm{d}}$ \\
& \pm 1.12 & \pm 0.01 & \pm 0.07 & \pm 0.42 & \pm 0.13 & \pm 0.19 \\
& $4.02^{\mathrm{bc}}$ & $0.36^{\mathrm{abc}}$ & $0.74^{\mathrm{bcd}}$ & $0.61^{\mathrm{cd}}$ & $0.42^{\mathrm{bcd}}$ & $0.75^{\mathrm{bcd}}$ \\
& \pm 0.46 & \pm 0.04 & \pm 0.05 & \pm 0.018 & \pm 0.10 & \pm 0.11 \\
& $2.02^{\mathrm{a}}$ & $0.25^{\mathrm{ab}}$ & $0.44^{\mathrm{a}}$ & $0.23^{\mathrm{ab}}$ & $0.13^{\mathrm{a}}$ & $0.39^{\mathrm{a}}$ \\
& \pm 0.87 & \pm 0.04 & \pm 0.07 & \pm 0.13 & \pm 0.06 & \pm 0.06 \\
& $4.20^{\mathrm{bc}}$ & $0.30^{\mathrm{ab}}$ & $0.56^{\mathrm{ab}}$ & $0.41^{\mathrm{abc}}$ & $0.37^{\mathrm{abc}}$ & $0.64^{\mathrm{bc}}$ \\
& \pm 1.10 & \pm 0.11 & \pm 0.07 & \pm 0.18 & \pm 0.13 & \pm 0.18 \\
& $4.99^{\mathrm{c}}$ & $0.52^{\mathrm{d}}$ & $0.96^{\mathrm{e}}$ & $0.81^{\mathrm{e}}$ & $0.61^{\mathrm{e}}$ & $1.23^{\mathrm{e}}$ \\
\hline
\end{tabular}

Values are means \pm standard deviations for 5 rats per diet group $(n=5)$. Values in the same column with similar superscript letters are not significantly different at $5 \%$ level $(p<0.05)$

The values for absolute organ weights of the experimental animals are shown in Table 2.The absolute organ weights of the rats fed the various experimental diets showed that the liver weight of rats fed Diet 4 was highest $(5.07 \pm 1.12 \mathrm{~g})$ and statistically different $(\mathrm{P}<0.05)$ from liver weights of rats fed Diets 6(2.02 $\pm 0.87 \mathrm{~g})$, Diet 3(2.50 $\pm 0.92 \mathrm{~g})$ and Diet $1(1.91 \pm 0.37 \mathrm{~g})$. Absolute heart weight of rats on Diet $8(0.52 \pm 0.11 \mathrm{~g})$ was highest but not statistically different from all other groups. This trend was observed in the kidney weights among the diet groups. Rats fed Diet 8 also had the highest absolute pancreas weight $(0.81 \pm 0.22 \mathrm{~g})$, spleen $(0.61 \pm 0.18 \mathrm{~g})$ and lungs $(1.23 \pm 0.10 \mathrm{~g})$, which were significantly higher $(\mathrm{P}<0.05)$ than values in other diet groups.

Table 3: Relative organ weights of rats at the end of feeding study (28days)

\begin{tabular}{lllllll}
\hline Diet group & Liver $(\mathrm{g})$ & Heart $(\mathrm{g})$ & Kidney g) & Pancreas $(\mathrm{g})$ & Spleen $(\mathrm{g})$ & Lungs $(\mathrm{g})$ \\
\hline & & & & & & \\
1 & $2.78^{\mathrm{a}}$ & $0.44^{\mathrm{a}}$ & $0.52^{\mathrm{a}}$ & $0.22^{\mathrm{a}}$ & $0.28^{\mathrm{b}}$ & $0.58^{\mathrm{bc}}$ \\
& \pm 0.04 & \pm 0.01 & \pm 0.41 & \pm 0.3 & \pm 0.05 & \pm 0.17 \\
& $3.16^{\mathrm{b}}$ & $0.28^{\mathrm{c}}$ & $0.67^{\mathrm{b}}$ & $0.34^{\mathrm{b}}$ & $0.24^{\mathrm{b}}$ & $0.60^{\mathrm{b}}$ \\
3 & \pm 0.06 & \pm 0.21 & \pm 0.25 & \pm 0.08 & \pm 0.03 & \pm 0.09 \\
& $4.01^{\mathrm{c}}$ & $0.25^{\mathrm{c}}$ & $0 . .60^{\mathrm{b}}$ & $0.57^{\mathrm{c}}$ & $0.27^{\mathrm{b}}$ & $0.55^{\mathrm{c}}$ \\
4 & \pm 0.14 & \pm 0.07 & \pm 0.18 & \pm 0.01 & \pm 0.01 & \pm 0.05 \\
& $3.26^{\mathrm{b}}$ & $0.41^{\mathrm{a}}$ & $0.65^{\mathrm{b}}$ & $0.46^{\mathrm{bc}}$ & $0.36^{\mathrm{a}}$ & $0.73^{\mathrm{a}}$ \\
5 & \pm 0.07 & \pm 0.11 & \pm 0.11 & \pm 0.04 & \pm 0.05 & \pm 0.09 \\
& $4.02^{\mathrm{c}}$ & $0.29^{\mathrm{c}}$ & $0.60^{\mathrm{b}}$ & $0.49^{\mathrm{bc}}$ & $0.34^{\mathrm{a}}$ & $0.61^{\mathrm{b}}$ \\
& \pm 0.46 & \pm 0.04 & \pm 0.51 & \pm 0.08 & \pm 0.02 & \pm 0.06 \\
7 & $3.18^{\mathrm{b}}$ & $0.39^{\mathrm{ab}}$ & $0 . .69^{\mathrm{b}}$ & $0.36^{\mathrm{b}}$ & $0.21^{\mathrm{b}}$ & $0.62^{\mathrm{b}}$ \\
& \pm 0.10 & \pm 0.02 & \pm 0.35 & \pm 0.13 & \pm 0.02 & \pm 0.01 \\
& $3.43^{\mathrm{b}}$ & $0.30^{\mathrm{bc}}$ & $0.56^{\mathrm{ab}}$ & $0.41^{\mathrm{bc}}$ & $0.31^{\mathrm{a}}$ & $0.64^{\mathrm{b}}$ \\
& \pm 1.01 & \pm 0.02 & \pm 0.35 & \pm 0.20 & \pm 0.03 & \pm 0.18 \\
& $3.05^{\mathrm{b}}$ & $0.32^{\mathrm{bc}}$ & $0.59^{\mathrm{ab}}$ & $0.51^{\mathrm{bc}}$ & $0.37^{\mathrm{a}}$ & $0.75^{\mathrm{a}}$ \\
\hline
\end{tabular}

Values are means $\pm S D$ for 5 rats per diet group $(n=5)$. Means in the same column bearing similar superscript letters were not significantly different at $5 \%$ level $(p<0.05)$.

For the relative organ weights (Table 3), rats fed Diet 3 and Diet 5 had the highest liver weight $(4.01 \pm 0.14 \mathrm{~g})$ and $(4.02 \pm 0.46 \mathrm{~g})$ respectively which are significantly higher than other groups at $(\mathrm{P}<0.05)$.The highest relative heart weight was observed in rats fed Diet 1 $(0.44 \pm 0.01 \mathrm{~g})$ which was significantly different $(\mathrm{P}<$ $0.05)$ from all other groups except Diets 4 (0.41 \pm $0.11 \mathrm{~g})$ and Diet $6(0.39 \pm 0.02 \mathrm{~g})$. Diet 6 produced rats with the highest relative kidney weight $(0.69 \pm 0.35 \mathrm{~g})$ which was only significantly higher than the values obtained in Diet $1(0.52 \pm 0.41)$. Rats on Diet 1 had the lowest relative pancreas weight $(0.22 \pm 0.3 \mathrm{~g})$ was statistically lower $(\mathrm{p}<0.05)$ than values produced by all other experimental animals. Relative spleen weight was highest in rats fed Diet $8(0.37 \pm 0.03 \mathrm{~g})$ but statistically higher than values obtained in Diets1,2,3 and 6.While 
Diet 8 produced rats with the highest lung weight $(0.75$ $\pm 0.15)$ which was statistically higher from values obtained in other diets except diet $4(0.73 \pm 0.09 \mathrm{~g})$.

Table 4: Haematological parameters of rats fed the experimental diet for 28 days

\begin{tabular}{|c|c|c|c|c|c|c|c|c|}
\hline Diet & $\begin{array}{l}\mathrm{Hb} \\
(\mathrm{g} / 100 \mathrm{ml})\end{array}$ & PCV (\%) & $\begin{array}{l}\text { WBC } \\
10^{-6} \mathrm{~mm}^{-3}\end{array}$ & $\mathrm{~N}(\%)$ & $\mathrm{L}(\%)$ & $\mathrm{E}(\%)$ & $\mathrm{B}(\%)$ & $\mathrm{M}(\%)$ \\
\hline 1 & $\begin{array}{l}10.75^{\mathrm{b}} \\
\pm 0.60\end{array}$ & $\begin{array}{l}35.5^{\text {bcd }} \\
\pm 2.08\end{array}$ & $\begin{array}{l}9500^{c} \\
\pm 605.5\end{array}$ & $\begin{array}{l}55.75^{\mathrm{a}} \\
\pm 3.30\end{array}$ & $\begin{array}{l}43.25^{\mathrm{a}} \\
\pm 2.5\end{array}$ & $\begin{array}{l}0.75^{\mathrm{b}} \\
\pm 0.06\end{array}$ & $\begin{array}{l}0.00^{\mathrm{a}} \\
\pm 0.00\end{array}$ & $\begin{array}{l}0.0 \\
\pm 0.00\end{array}$ \\
\hline 2 & $\begin{array}{l}12.0^{\text {be }} \\
\pm 0.6\end{array}$ & $\begin{array}{l}36.33^{\text {cd }} \\
\pm 1.53\end{array}$ & $\begin{array}{l}9033.33^{\mathrm{bc}} \\
\pm 550.76\end{array}$ & $\begin{array}{l}54.67^{\mathrm{a}} \\
\pm 3.79\end{array}$ & $\begin{array}{l}45.0^{\mathrm{a}} \\
\pm 3.46\end{array}$ & $\begin{array}{l}0.00^{\mathrm{a}} \\
\pm 0.00\end{array}$ & $\begin{array}{l}0.00^{\mathrm{a}} \\
\pm 0.0\end{array}$ & $\begin{array}{l}0.00^{\mathrm{a}} \\
\pm 0.00\end{array}$ \\
\hline 3 & $\begin{array}{l}11.36^{\mathrm{b}} \\
\pm 0.36\end{array}$ & $\begin{array}{l}33.5^{\mathrm{bc}} \\
\pm 1.73\end{array}$ & $\begin{array}{l}7850.0^{\mathrm{b}} \\
\pm 369.69\end{array}$ & $\begin{array}{l}53.25^{\mathrm{a}} \\
\pm 2.22\end{array}$ & $\begin{array}{l}41.75^{\mathrm{a}} \\
\pm 1.71\end{array}$ & $\begin{array}{l}0.05^{\mathrm{a}} \\
\pm 0.01\end{array}$ & $\begin{array}{l}0.25^{\mathrm{a}} \\
\pm 0.05\end{array}$ & $\begin{array}{l}0.25 \\
\pm 0.01\end{array}$ \\
\hline 4 & $\begin{array}{l}11.27^{\mathrm{b}} \\
\pm 0.64\end{array}$ & $\begin{array}{l}34.0^{\text {bd }} \\
\pm 1.73\end{array}$ & $\begin{array}{l}8633.35^{\text {abc }} \\
\pm 1021.44\end{array}$ & $\begin{array}{l}53.0^{\mathrm{a}} \\
\pm 4.58\end{array}$ & $\begin{array}{l}47.0^{\mathrm{b}} \\
\pm 4.58\end{array}$ & $\begin{array}{l}0.00^{\mathrm{a}} \\
\pm 0.00\end{array}$ & $\begin{array}{l}0.00^{\mathrm{a}} \\
\pm 0.00\end{array}$ & $\begin{array}{l}0.00^{\mathrm{a}} \\
\pm 0.00\end{array}$ \\
\hline 5 & $\begin{array}{l}11.47^{\mathrm{bc}} \\
\pm 0.92\end{array}$ & $\begin{array}{l}32.67^{\mathrm{ab}} \\
\pm 3.06\end{array}$ & $\begin{array}{l}8733.35^{\mathrm{abc}} \\
\pm 351.19\end{array}$ & $\begin{array}{l}57.0^{\mathrm{b}} \\
\pm 6.08\end{array}$ & $\begin{array}{l}42.0^{\mathrm{a}} \\
\pm 5.29\end{array}$ & $\begin{array}{l}0.67^{\mathrm{b}} \\
\pm 0.08\end{array}$ & $\begin{array}{l}0.23^{\mathrm{b}} \\
\pm 0.08\end{array}$ & $\begin{array}{l}0.00^{\mathrm{a}} \\
\pm 0.00\end{array}$ \\
\hline 6 & $\begin{array}{l}9.85^{\mathrm{a}} \\
\pm 0.76\end{array}$ & $\begin{array}{l}29.79^{\mathrm{a}} \\
\pm 2.5\end{array}$ & $\begin{array}{l}8300.0^{\mathrm{ab}} \\
\pm 1334.0\end{array}$ & $\begin{array}{l}55.5^{\mathrm{a}} \\
\pm 2.65\end{array}$ & $\begin{array}{l}44.0^{\mathrm{a}} \\
\pm 3.37\end{array}$ & $\begin{array}{l}0.25^{\mathrm{a}} \\
\pm 0.5\end{array}$ & $\begin{array}{l}0.25^{\mathrm{b}} \\
\pm 0.05\end{array}$ & $\begin{array}{l}0.00^{\mathrm{a}} \\
0.00\end{array}$ \\
\hline 7 & $\begin{array}{l}11.60^{\mathrm{bc}} \\
\pm 0.71\end{array}$ & $\begin{array}{l}35.75^{\text {bcd }} \\
\pm 2.36\end{array}$ & $\begin{array}{l}9225.0^{\mathrm{bc}} \\
\pm 613.05\end{array}$ & $\begin{array}{l}56.5^{\mathrm{a}} \\
\pm 3.70\end{array}$ & $\begin{array}{l}41.25^{\mathrm{a}} \\
\pm 4.03\end{array}$ & $\begin{array}{l}0.00^{\mathrm{a}} \\
\pm 0.00\end{array}$ & $\begin{array}{l}0.00^{\mathrm{a}} \\
\pm 0.00\end{array}$ & $\begin{array}{l}0.00^{\mathrm{a}} \\
\pm 0.00\end{array}$ \\
\hline 8 & $\begin{array}{l}12.56^{\mathrm{c}} \\
\pm 0.71\end{array}$ & $\begin{array}{l}37.2^{\mathrm{c}} \\
\pm 1.30\end{array}$ & $\begin{array}{l}9640^{\mathrm{e}} \\
\pm 350.71\end{array}$ & $\begin{array}{l}58.4^{\mathrm{b}} \\
\pm 2.07\end{array}$ & $\begin{array}{l}45.75^{\mathrm{a}} \\
\pm 2.22 \\
\end{array}$ & $\begin{array}{l}0.20^{\mathrm{a}} \\
\pm 0.05\end{array}$ & $\begin{array}{l}0.20^{\mathrm{a}} \\
\pm 0.05\end{array}$ & $\begin{array}{l}0.00^{\mathrm{a}} \\
\pm 0.00\end{array}$ \\
\hline
\end{tabular}

Values are means \pm standard deviations for 5 rats per diet group $(n=5)$ Values in the same column with similar superscript letters are not significantly different at $5 \%$ level $(p<0.05)$

LEGEND:HB - Haemoglobin, PCV -packed cell volume, WBC-white blood cells, N - Neutrophils, EEosinophils, M-monocytes, L - Lymphocytes, B Basophils.

Table 4 shows the haematological parameters of the experimental animals. It was observed that the haemoglobin values for rats fed the Reference Diet (8) was highest $(12.56 \pm 01 \mathrm{~g} / 100 \mathrm{ml})$ and was not significantly different from Diet 2(12.0 \pm 0.6 $\mathrm{g} / 100 \mathrm{ml})$ and Diet $7(11.60 \pm 0.71 \mathrm{~g} / 100 \mathrm{ml})$ but significantly higher $(\mathrm{P}<0.05)$ than the other groups. The same trend was observed in values for packed cell volume. The white blood cells was highest in Diet $8\left(9640 \pm 350.7110^{-6} \mathrm{~min}^{-3}\right)$. Neutrophils $(\mathrm{N})$ were highest in diet $8(58.4 \pm 2.07 \%)$ which was significantly different from other diet groups except diet 5 which had $57.0 \pm 6.08 \%$.

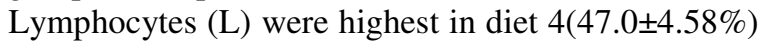
which was significantly different from other diet groups. Eosinophils were highest in diet1 $(0.75 \pm 0.96)$ which was significantly higher than other diet groups except diet 5(0.67 \pm 0.58$)$.Diets 5 and 6 had similar values for basophils (B) which are significantly different from the other groups. Monocytes were not detected in the blood sample of the rats fed the various diets except in diet $3\left(0.25 \pm_{0.5}\right)$ however this value did not differ significantly from the other groups.
The decreased weight observed among the rats fed Diet 6 may be due to the low protein level and this is supported by (Cousin et al., (1981)) who reported weight loss in rats fed low protein diets. For the raw diet, the negative weight change may be attributed to the presence of the ant nutritional factors prominent among which tannin and trypsin inhibitors known to interfer with protein metabolism.A similar observation was made by various authors ( Ogun et al.,(1989) and Mole et al (1990)) in which the presence of trypsin inhibitor activity and tannin in uncooked feed caused diminished growth in rats, chicken and other experimental animals, however (Shaahu et al., (2014)) in their own study revealed that the final weights of the rabbits fed toasted lablab seed diets from 0-5 weeks were similar to those fed control diet, and also similar to those fed the raw seed diets. Other experimental diet showed weight increases in the rats, with the reference diet(Diet 8)having the highest value which is significantly different from the other experimental diets. This confirmed that the reference diet was superior to the other diets. However, the cooked diet supported growth more than other treatment groups. This suggested that the heat treatments reduced the levels of the inherent antinutrients to the extent that the residual quantities did not interfere with protein metabolism. This agrees with the reports of (Kaankuka et al (2000), Pathak and Ranjahan (1997) that dry heating (toasting) of legume seeds are less 
effective in the removal of ant nutritional substances and thus, performance of animals than wet heating.

The variations in the values of the absolute organ weights showed no specific trend but for the liver weights.Diets, 1,3 and 6 had liver weights statistically different from other treatment groups.This may be attributed to the fact that the liver as the detoxifying organ is usually affected by toxins (antinutrients) and also protein deficiency. This observation disagrees with some studies including (Onyeike and Nkwuzor (2006)) which reported improvement in the organ weight of rats fed heat processed sample of cashew nut flour which they attributed to destruction of toxicants in the flour by heat.

The values for haemoglobin $(\mathrm{Hb})$ and packed cell volume(PCV) for Diets 2 and 8 were higher than other groups.They were not significantly different suggesting that cooking though better than other heat treatments in destroying the antinutrient but the level of antinutrients inherent in the raw seeds and the residual in the treated seeds had little effect on the parameters. The main function of the white blood cells (WBC) is body defence and since processing did not affect the WBC levels in a particular way, it therefore means that there was neither under production or overproduction of the cells as are the cases in either protein energy malnutrition or infection and toxicity. The differences in the values for the differential counts also showed no specific trend. Altered blood parameters in animals exposed to toxicants have been reported (Amaefule and Nwagbara, (2004) .The results of this study suggest that the levels of residual antinutrients in the diets may not be high enough to elicit obvious haematological responses since most of the haematological parameters did not differ significantly in the animals on the experimental diets compared with animals on the reference diet.

Conlusion:Heat-treated kudzu formulations supported growth in the experimental animals, it can support same in higher animals including man.However, there were no specific trend in organ weight and biochemical changes, there is therefore a need to carry out further biochemical nveatigations and pathological examinations on the organs of these animals to rule out cellular damages.It is when this is done, that dry or wet heat treated kudzu could be recommended for either animal feed or human food.

\section{REFERENCES:}

Akande K.E; Doma U.D; Agu H.O;Adamu H.M. (2010). Major antinutrient found in plant protein souces: Their effect on nutrition. Pakistan journal of nutrition $9(8) ; 827-832$.

Amaefule, K.U; Nwagbara, N.N (2004). The effect of processing of Pigeonpea (Cajanus cajan) seed meal and Pigeo pea seed meal based diets by pullets. International Journal of Poultry Science 3 (8): 543-546.

Cousin B.W; Tanksley T.D; Zebrowska (1981).Nutrient digestibility and performance of pigs fed sorghum varying in tannin concentration. Journal of animal science 53: $1524-1537$.

Ifeanacho M.O; Abbey B.W; Ayalogu E.O. (2007).Chemical Composition of African Kudzu (Pueraria phaseoloides roxb.benth) seeds.Nigerian Journal of Nutritional sciences 28 (2) 61-67.

Ifeanacho M; Abbey B.W. Ayalogo E.O. (2008). Effects of heat treaments on the African Kudzu (Pueraria Phaseoloides, Roxb. Benth) seeds. Nigerian Journal of Nutritional Sciences, 28 (2), 318-329

Kaankuka F.G; Balogun T.F;Yaakugh I.D.I. (2000). Effect of duration of cooking raw full fat soybeans on dug matter digestibility and energy utilization by young pigs. Proceedings of the Annual Conference of Nigeria Society for Animal Production held at Michael Okpara University of Agriculture Umudike, Nigeria: 2000) 191-193.

Kaufman, H. W. (1986).Interaction of inositol phosphotases with mineralized tissues. In: Phytic Acid Chemistry and Applications, Graf E. (ed) Pilatnis press. Minneapolis. MN p. 303.

Maria C.V.P; Ryszard A; Alberta N.A.A; Joyce I.B;Hyun-Jung C;Maria a.M-C; Claire D.(2015. Achievements and challenges in improving the nutritional quality of food legume. Critical reviews in plant sciences 34 (1-3),72-77.

Mole S; Rogler; Morell C.J; Butler L.G. (1990). Herbivore growth reduction of tannins; use of wildbaver ratio techniques and manipulation of salivary protein production to elucidate mechanism of action.Biochemical systematics and Ecology 18: 183 - 187 . 
Variation in Body Weight, Organ Weight and Haematological Parameters

Norusis, M. J. (1986). One Way Analysis of variance $\mathrm{spp} / \mathrm{pc}$ for the Ibm Pc/XT/ AT/ SPSS Inc. Michigan

Ogun P.O; Markakis P;Chenoweth W. (1989). Effect of processing on certain ant nutrients in cowpea (Vigna Unguiculata). J. Food Sci. 54 : 1084 1085.

Onyeike, E. N; Nkwuzor,N. F (2006). Evaluation of the nutritional quality of diets formulated from processed cashew nut seed. (Anarcardium occidentale) flours Scientia Africana 5(1):5365.

Pathak, N. N; Ranjahan, S. K (1997). Nutritional studies with salseed - meal as a component of fisher ratios in the large white Yorkshire Pigs. Ind. J. of Animal Sci. 53: 424 - 427.

Rajeev Bhat; Karim, A.A (2009). Exploring the Nutritional Potential of wild and underutilized legumes. Comprehensive Reviews in Food Science and Safety 8 (4): 305-331.

Rebello C.J;Greenway F.L; Finley J.W.(2014).A review of the nutritional value of legumes and their benefits on obesity and its related comorbidities.Obesity Review 15(5):392-407.

Shaahu D.T;Carew S.N; Dzungwe N. (2014). Effect of Using Raw or processed lablab seed as major protein source in diets on the economics of feeding and growth performance of rabbits. Journal of Agriculture and Veterinary Science. 7(5) 22-26
Siddhuraju, P; Becker K.( 2003). Comparative nutritional evaluation of differential processed mucuna seeds (Mucuna pruriens (L) D.C. var. utilis (wall ex weight) Baker ex Burck) on growth performance, feed utilization and body composition in Nile tilapia (Oreochromis nitoticus( L). Agriculture research 34:487-500.

Siddhuraju P;Osoniyi O;Makkar H.P.S; Becker K. (2002). Effect of soaking and ionising radiation on various anti-nutritional factors of seed from different species of an unconventional legume, sesbanic and a common legume, green grain (vigna radiata). Food Chemistry 79; 277-281.

Stanner S.A; Hughes J;Kelly C.N; Buttriss J. (2004). A review of the epidemiological evidence for the 'antioxidant hypothesis' Public Health Nutrition. 7:407-422.

Yusuf A.A; Mofio B.M; Ahmed A.B. (2007). Nutrient content of pride of Barbados (Caesalpinia pulcherrima) seeds. Pakistan Journal of Nutrition 6:117-121. 